\title{
MICROBIOLOGICAL AND CHEMICAL CHANGES IN FRESHWATER PRAWN (MACROBRACHIUM ROSEMBERGII) STORED UNDER REFRIGERATION
}

\author{
Mauro Faber de Freitas Leitão*; Daniel de Pinho Astacio Rios \\ Departamento de Tecnologia de Alimentos, Faculdade de Engenharia de Alimentos, UNICAMP, Campinas, SP, Brasil
}

Submitted: June 30, 1999; Returned to authors for corrections: March 24, 2000; Approved: June 26, 2000

\begin{abstract}
Microbiological and chemical changes were evaluated in freshwater prawn stored under refrigeration at $0^{\circ} \mathrm{C}$ and $5^{\circ} \mathrm{C}$ during 10 days, with special emphasis on indole production as a chemical spoilage indicator. The total psychrotrophic and indole positive microflora were mainly mesophilic, with indole positive microorganisms being less than $10 \%$ of the total microflora after 10 days storage under refrigeration. Bacteria from Enterobacteriaceae and Vibrionaceae families prevailed among the isolated indole positive strains. The use of the Most Probable Number-MPN method, using tryptone broth as culture medium, was the most reliable approach for the quantitative evaluation of the indole positive microflora. The stored samples showed increases in $\mathrm{pH}$, L-tryptophan and total volatile bases (TVB), which were more intensive at $5^{\circ} \mathrm{C}$. The psychrotrophic counts and TVB values of samples stored at $0^{\circ} \mathrm{C}$ were lower than the recommended limits $\left(10^{7} \mathrm{CFU} / \mathrm{g}\right.$ and $30 \mathrm{mg} \mathrm{N} / 100 \mathrm{~g}$, respectively), even after 10 days storage. However, in samples stored at $5^{\circ} \mathrm{C}$, these values were reached after 10 and 5 days, respectively. The presence of indole in levels above the limit recommended by FDA/USA $(25 \mu \mathrm{g} / 100 \mathrm{~g})$ was confirmed in only one sample, suggesting that this substance, alone, wouldn't be a good indicator of freshwater prawn quality stored under refrigeration.
\end{abstract}

Key words: freshwater prawn, shelf life, indole

\section{INTRODUCTION}

The evaluation of general quality and shelf life of fish and fish products is based on organoleptic, chemical and microbiological tests. Concerning the chemical tests, dosages of trimethylamine-TMA, total volatile basis-TVB, hypoxanthine, tiobarbituric acid-TBA, indole, etc, are commonly employed $(6,9,12,14,15,22)$. However, in quality evaluation of crustaceans, particularly shrimps, indole dosage is probably the chemical index most commonly applied $(6,9,12,20,22)$.

Indole formation depends exclusively on development of bacteria producing enzymes called tryptophanases, that oxidize the free L-tryptophan present in muscle tissues producing indole, skatole (methyl indole) and indolacetate (16). Several bacteria genera have species that are indole positive, particularly
Proteus, Escherichia, Edwardsiella, Flavobacterium, Aeromonas, Plesiomonas, Bacillus, etc $(20,21)$.

Indole detection has long been used as an indicator of shrimp spoilage. Based on data collected by the Food and Drug Administration-FDA/USA, indole levels in fresh shrimps are lower than $1 \mu \mathrm{g} / 100 \mathrm{~g}$ and there is a good correlation between indole concentration and organoleptic evaluation (17). According to these studies, shrimps are classified in class 1 , when they do not show any organoleptic evidence of spoilage; when spoilage is first detected, they go to class 2, and when spoilage is clearly defined they are classified in class 3 ; the corresponding indole levels are $<25 \mu \mathrm{g} / 100 \mathrm{~g}$ for class 1 , and $>25 \mu \mathrm{g} / 100 \mathrm{~g}$ for classes 2 and 3 . Based on these data, FDA defined a maximum allowable indole level of $25 \mu \mathrm{g} / 100 \mathrm{~g}$ for canned and pre- cooked frozen shrimps (17).

\footnotetext{
* Corresponding author: Mailing address: Departamento de Tecnologia de Alimentos, FEA, UNICAMP, CEP 13083-970, Campinas, SP, Brasil, Fax (+5519) 289-

3617.E-mail: leitao@correionet.com.br
} 
In Brazil, indole detection is not usually employed for quality evaluation of fresh and processed shrimps. However, according to São Paulo state legislation, the maximum allowable indole level for canned shrimps is $4 \mu \mathrm{g} / 100 \mathrm{~g}$ (19).

Most of the published papers in the literature concerning the microbial spoilage are related with shrimps of marine origin (particularly Penaeus spp). Only a few studies are available on freshwater shrimps or prawns (genus Macrobrachium and others), which are assuming increasing economic importance since they are the main species utilized in aquaculture programs in Brazil and other countries. Most of these studies are related to the influence of storage temperature on indole production and spoilage (2) and also to qualitative evaluation of the indole positive microflora developing at different temperatures $(20,21)$. However, there is a total lack of conclusive studies related to development or optimization of methods for the quantitative study of this microflora.

Based on these considerations this research was conducted to monitor the microbiological and chemical changes in freshwater prawn during storage under different refrigeration temperatures and to improve the methodology for the quantitative evaluation of the indole positive microflora.

\section{MATERIALS AND METHODS}

\section{Material}

Samples of freshwater prawn (Macrobrachium rosembergii) were captured in rearing ponds from Instituto de Pesca, Secretary of Agriculture, São Paulo, Brazil, located in Pindamonhangaba, São Paulo state.

After being captured, the prawns were introduced in plastic bags ( $2 \mathrm{~kg}$ each) and stored in isothermic boxes containing crushed ice, followed by immediate transport to the UNICAMP laboratory, with an average delay of $4 \mathrm{~h}$ between sampling and starting the analysis.

\section{Experimental procedures}

In the laboratory, the prawns were split in two $1 \mathrm{~kg}$ portions, packed in individual plastic bags and stored in commercial refrigerators at temperatures of $0^{\circ} \mathrm{C}$ and $5^{\circ} \mathrm{C}$. The samples stored at $0^{\circ} \mathrm{C}$ were completely covered with crushed ice, without direct contact to avoid microbial cross-contamination and washing of soluble compounds.

At 0,5 , and 10 days intervals, samples of muscle tissue (with cephalotorax and tail removal) were asseptically taken and submitted to microbiological and chemical analysis. For the microbiological analysis $10 \mathrm{~g}$ portions were homogeneized in $90 \mathrm{ml}$ of peptone water while the original muscle tissue without any dilution was used for the chemical analysis.

All the experiments were repeated 3 times, at intervals of approximately 30 days between each repetition, using exactly the same procedures.

\section{Chemical Analysis:}

pH - 20g portions of muscle tissue were homogeneized in $20 \mathrm{ml}$ of distilled water, followed by $\mathrm{pH}$ determination in a Metrohm $\mathrm{pH}$ meter $(1,10)$.

Indole - Indole detection was based on the modified colorimetric method as proposed by Cheuk and Finne (3).

Free L-tryptophan - Based on the colorimetric method proposed by Contreras and Guimarães (4).

Total Volatile Bases - TVB - Based on extraction with trichoroacetic acid followed by distillation $(1,8,10)$.

\section{Microbiological Analysis:}

Total psychrotrophic count - done using Plate Count AgarPCA agar (BD), as culture medium, with inoculation by spread plate followed by incubation at $20^{\circ} \mathrm{C}$ during $72 \mathrm{~h}$. Results were expressed as CFU/g (23).

Indole positive microflora - Three different approaches were used for the counts:

1. Most Probable Number-MPN- using tryptone broth as culture medium, with 3 tubes per dilution, incubation at $20^{\circ} \mathrm{C}$ during $72 \mathrm{~h}$, followed by addition of $0.5 \mathrm{ml}$ of Kovacs reagent, considering as positives the tubes with formation of a red ring. Results as MPN/g (16, 23).

2. Indirect count with isolation of representative colonies from the PCA plates (minimum of 5 colonies), followed by inoculation of each one in tubes of tryptone broth, with incubation at $20^{\circ} \mathrm{C}$ during $72 \mathrm{~h}$, and subsequent test for indole production by adding Kovacs reagent. The indole positive count was calculated based on the total count and the percent isolated cultures that showed an indole positive reaction.

3 . Indirect count in tryptone agar plus $0.5 \% \mathrm{NaCl}$ (TP agar), with inoculation by spread plate and incubation at $20^{\circ} \mathrm{C}$ during 72h. After incubation a number of representative colonies (minimum of 5 colonies) were presumptively tested for indole production by streaking on filter paper impregnated by Ehrlich reagent (16); the presumptively indole positive cultures (wine coloured streak on filter paper) were isolated in trypticase soy agar and confirmed as indole positive by inoculation in tryptone broth and further test for indole production $(16,23)$. Finally, the indole positive count was calculated based on the total count and the percent indole positive cultures.

Identification of indole positive cultures and evaluation of indole production potential according to the incubation temperature.

The isolated cultures confirmed as indole producers were identified up to genus or species levels according to Holt et al. (7), and using commercial kits for the biochemical tests, particularly Crystal system (BD), and API 20 E (BiolabMerieux).

For the evaluation of indole production potential in prawns, portions of muscle tissue were homogeneized in equal weight of distilled water (1:1), transferred to culture tubes (10g/tube), 
followed by sterilization $\left(121^{\circ} \mathrm{C} / 15 \mathrm{~min}\right)$; after cooling, individual tubes were inoculated with representative indole positive cultures originally isolated from the prawn samples, followed by incubation at $4{ }^{\circ} \mathrm{C}$ and $10^{\circ} \mathrm{C}$ during 10 days and further indole analysis, according to the method proposed by Chenk and Finne (3).

\section{RESULTS AND DISCUSSION}

The total psychrotrophic counts of freshwater prawns were relatively high, with an average of $5.2 \mathrm{log}$ CFU/g (Figs. 1 and 2). However, these values are not unusual when compared to other data; according to the International Commission on Microbiological Specifications for Foods-ICMSF (11), fresh seafoods show counts varying from $\log 3.0$ up to $\log 7.0 \mathrm{CFU} /$ $\mathrm{g}$ with different conditions affecting the contamination levels. In our specific situation, aspects like high water temperatures and organic matter levels in the rearing ponds could contribute to an increase in the microbial populations. Anyway, these average values are bellow the usual limit of $\log 7.0 \mathrm{CFU} / \mathrm{g}$ above which foods in general show organoleptic evidences of spoilage based on odor, colour and texture $(11,12)$. Figs. 1 and 2 also show that there were differences between the counts at $0^{\circ} \mathrm{C}$ and $5^{\circ} \mathrm{C}$ during the 10 days storage period. At $5^{\circ} \mathrm{C}$, after 5 days storage there was a lag or a very small increase in the counts, followed by a definitive increase after 10 days storage; however, at $0^{\circ} \mathrm{C}$, the counts remained constant or even decreased after the 10 days storage period. These results suggest that the original prawn microflora was mesophilic being able to grow at refrigeration temperatures only after a long lag phase. Similar results were reported by other authors working with freshwater fish in tropical areas, with this slow growth rate being considered one of the main factors explaining the longer shelf life of tropical fish when first stored at refrigeration temperatures $(5,13)$.

The comparative evaluation of different quantitative methods for counting the indole positive microflora showed that the MPN procedure gave the most consistent and reliable results, being the method of choice for counting indole positive microorganisms during the storage of prawns under refrigeration. When employing the indirect methods, the final results are delayed, because it is necessary to isolate representative colonies from the plates and test them individually for indole production, in order to get the counts of indole positive microorganisms. Besides being time consuming, this procedure requires testing of a large number of colonies in order to get reliable results. All these drawbacks make these indirect procedures inadequate for quality control purposes where aspects like easy performance and rapid results are essential.

Table 1 shows the results of indole positive counts in refrigerated prawns stored during 10 days. They indicate that

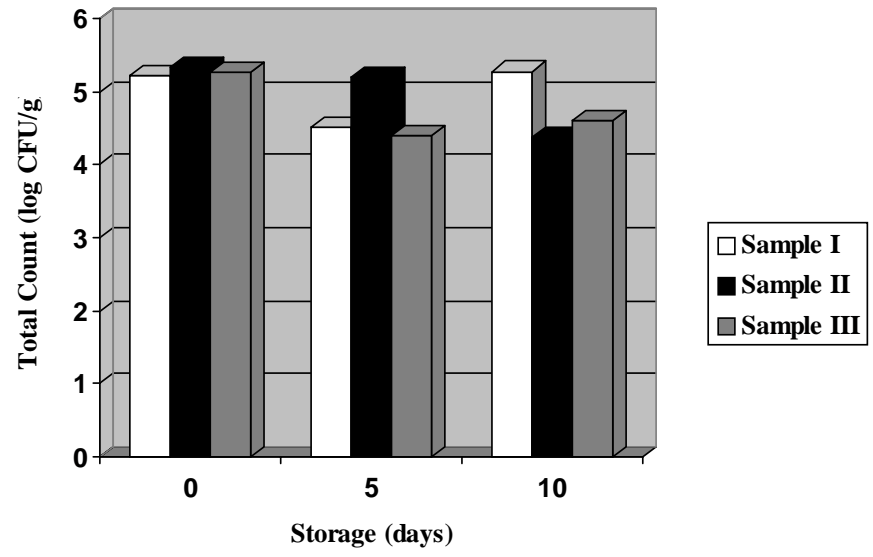

Figure1. Changes in the total psychrotrophic counts in freshwater prawns during storage at $0^{\circ} \mathrm{C}$ during 10 days

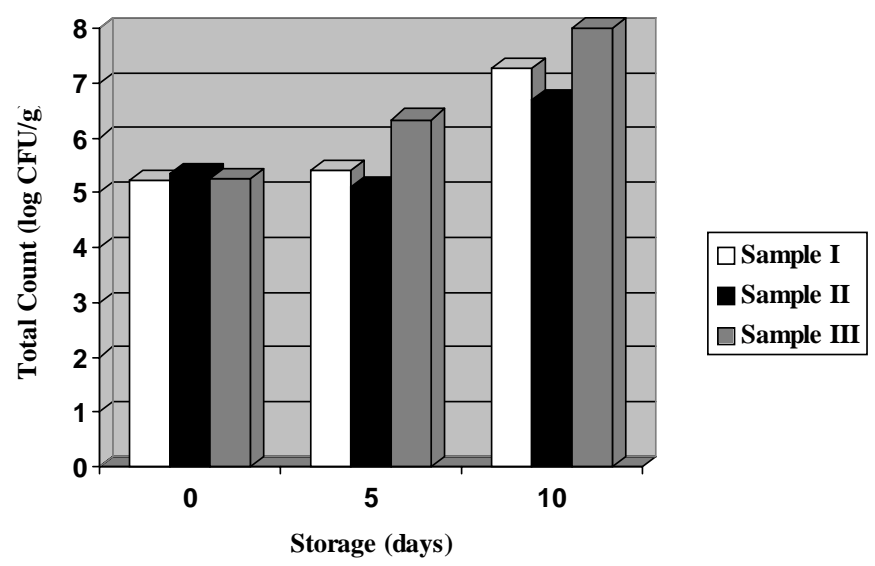

Figure 2. Changes in the total psychrotrophic counts in freshwater prawns during storage at $5^{\circ} \mathrm{C}$ during 10 days

the indole positive microflora is only a small fraction of the total microflora, particularly after 5 and 10 days storage at $0^{\circ} \mathrm{C}$. Even at $5^{\circ} \mathrm{C}$, when some microbial growth was evident, the indole positive microflora didn't show an extensive growth (except in sample III), indicating that it was also originally mesophilic.

These results agree, too, with the ones reported by Chang et al. (2) and Shamshad et al. (20). These authors showed that spoilage and indole production in shrimps stored under refrigeration were highly temperature dependent. Indole was not produced at $4^{\circ} \mathrm{C}$, while at $12^{\circ}, 20^{\circ}$ and $35^{\circ} \mathrm{C}$ it was produced in high levels. Based on these results, the National Research Council of USA (17) concluded that mesophilic bacteria are the main indole producing microorganisms and that the dosage of this compound, alone, wouldn't be a reliable index to indicate the spoilage of refrigerated shrimps. However, when applied in conjunction with physical and chemical methods, the concentration of indole is a good indicator of spoilage or, at least of improper storage under refrigeration. 
Table 1. Changes in the indole positive microflora according to different counting methods during storage of freshwater prawn at $0^{\circ}$ and $5^{\circ} \mathrm{C}$

\begin{tabular}{|c|c|c|c|c|c|c|c|}
\hline \multirow{3}{*}{ Sample } & \multirow{3}{*}{$\begin{array}{l}\text { Storage Time } \\
\text { (days) }\end{array}$} & \multicolumn{6}{|c|}{ Counting Methods } \\
\hline & & \multicolumn{2}{|c|}{ PCA agar $(\log \mathrm{CFU} / \mathrm{g})$} & \multicolumn{2}{|c|}{ PT agar (log CFU/g) } & \multicolumn{2}{|c|}{ Tryptone broth $(\log$ MPN/g) } \\
\hline & & $0^{\circ} \mathrm{C}$ & $5^{\circ} \mathrm{C}$ & $0^{\circ} \mathrm{C}$ & $5^{\circ} \mathrm{C}$ & $0^{\circ} \mathrm{C}$ & $5^{\circ} \mathrm{C}$ \\
\hline \multirow[t]{3}{*}{ I } & 0 & 4.1 & 4.1 & - & - & $>4.0$ & $>4.0$ \\
\hline & 5 & $<3.0$ & $<3.0$ & $<3.0$ & $<3.0$ & $<3.0$ & $<3.0$ \\
\hline & 10 & 4.2 & $<3.0$ & $<3.0$ & $<3.0$ & $<3.0$ & 1.6 \\
\hline \multirow[t]{3}{*}{ II } & 0 & 5.1 & 5.1 & 5.3 & 5.3 & 4.6 & 4.6 \\
\hline & 5 & $<3.0$ & $<3.0$ & $<3.0$ & 4.2 & 1.6 & 2.4 \\
\hline & 10 & $<3.0$ & $<3.0$ & $<3.0$ & $<3.0$ & 2.2 & 3.6 \\
\hline \multirow[t]{3}{*}{ III } & 0 & 4.9 & 4.9 & 4.8 & 4.8 & 3.6 & 3.6 \\
\hline & 5 & 3.7 & 6.0 & 4.1 & 5.8 & 3.4 & 5.0 \\
\hline & 10 & 3.9 & 7.3 & 3.8 & 7.5 & 2.6 & 5.7 \\
\hline
\end{tabular}

Several different indole positive bacteria were isolated and identified. There was a prevalence of bacteria of the Enterobacteriaceae family, particularly Citrobacter sp. (36.4\%), Pantoea agglomerans $(9.1 \%)$ and Leclercia adecarboxylata $(9.1 \%)$. Bacteria of the Vibrionaceae family, including Aeromonas hydrophila (27.2\%), Aeromonas sobria $(9.1 \%)$ and Aeromonas veronii $(9.1 \%)$, were also identified. Therefore, the results suggest that Gram negative, fermentative, mesophilic bacteria are the main indole producing microorganisms present in the freshwater prawn microflora.

Strains of Citrobacter sp and Aeromonas hydrophila, the prevailing indole positive microorganisms in the microflora, were inoculated in sterilized prawn muscle tissue and incubated at $4^{\circ}$ and $10^{\circ} \mathrm{C}$ during 10 days. The results showed that Citrobacter $s p$ was an active indole producer at $10^{\circ} \mathrm{C}$, with $>100 \mu \mathrm{g} / 100 \mathrm{~g}$, while Aeromonas hydrophila was not so efficient. However, at $4^{\circ} \mathrm{C}$ there was no detectable indole production, even after 10 days storage.

Smith et al. (21) evaluated the total and indole positive microflora of white shrimps (Penaeus setiferus) stored at different temperatures. The authors showed that indole positive cultures represented only $2.6 \%$ of the total population, with a prevalence of Flavobacterium spp (52.4\%), Aeromonas spp. $(23.8 \%)$, Proteus spp (21.4\%) and Yersinia spp (2.5\%), without detection of Escherichia coli. To our knowledge, this is the only research on indole positive microorganisms in fish products. However, it is important to point out that this research was carried out with shrimps of marine origin and captured in temperate waters, conditions quite different from the ones prevailing in this actual research.

The storage temperature also influenced $\mathrm{pH}$ and the levels of L-tryptophan and total volatile bases (Table 2).
There was an increase in $\mathrm{pH}$ during storage, probably due to amines formation by aminoacids decarboxylation (12). The increase in tryptophan levels was more evident at $5^{\circ} \mathrm{C}$ than at $0^{\circ} \mathrm{C}$; however it is very difficult to relate this increase with proteolysis levels, because a simultaneous reduction in tryptophan due to bacterial growth would be expected.

Total volatile bases (TVB) showed an increase, particularly at $5^{\circ} \mathrm{C}$; at this temperature, values above $30 \mathrm{mgN} / 100 \mathrm{~g}$, considered the maximum allowable limit $(9,17,22)$, were reached after 5 days storage at $5^{\circ} \mathrm{C}$. A correlation between TVB values and total psychrotrophic plate counts was noticed. The counts of samples stored at $5^{\circ} \mathrm{C}$ were above $\log 7.0-8.0 \mathrm{CFU} / \mathrm{g}$ (indicating spoilage) and simultaneous TVB levels $>30 \mathrm{mg}$ $\mathrm{N} / 100 \mathrm{~g}$, while at $0^{\circ} \mathrm{C}$ the counts were bellow $\log 6.0 \mathrm{CFU} / \mathrm{g}$ and TVB values $<30 \mathrm{mg} \mathrm{N} / 100 \mathrm{~g}$.

Based on the detection limit of the method applied $(25 \mu \mathrm{g} /$ $100 \mathrm{~g}$ ), indole was not detected in the examined refrigerated prawn samples, stored both at $0^{\circ} \mathrm{C}$ and $5^{\circ} \mathrm{C}$ during 10 days. However, indole levels around $100 \mu \mathrm{g} / 100 \mathrm{~g}$ were detected in one repetition, in samples stored at $5^{\circ} \mathrm{C}$, presenting counts of $5.7 \log \mathrm{CFU} / \mathrm{g}$ indole positive microorganisms. This suggests that a high increase in the population of indole positive microorganisms is necessary before indole becomes detectable in the stored samples. The results also suggest that due to the mesophilic nature of the indole positive microflora the spoilage of refrigerated prawn samples (as reflected by total psychrotrophic counts above $\log 7.0 \mathrm{CFU} / \mathrm{g}$ and TVB values $>30 \mathrm{mg} \mathrm{N} / 100 \mathrm{~g}$ ) is not necessarily related with a simultaneous increase in indole levels. It is also important to consider that the original tryptophan levels vary according to the shrimp or prawn species. Nip et al. (18) mentioned that tryptophan levels are 10 times lower in freshwater species of Malaysian prawn 
Table 2. Changes in $\mathrm{pH}$, free L-tryptophan and total volatile bases (TVB) during storage of freshwater prawn at $0^{\circ} \mathrm{C}$ and $5^{\circ} \mathrm{C}$

\begin{tabular}{|c|c|c|c|c|c|c|c|}
\hline \multirow{3}{*}{ Sample } & \multirow{3}{*}{$\begin{array}{c}\text { Storage Time } \\
\text { (days) }\end{array}$} & \multicolumn{6}{|c|}{ Analysis } \\
\hline & & \multicolumn{2}{|c|}{$\mathrm{pH}$} & \multicolumn{2}{|c|}{ Free L-tryptophan $(\mathrm{mg} / 100 \mathrm{~g})$} & \multicolumn{2}{|c|}{ TVB (mg N/100g) } \\
\hline & & $0^{\circ} \mathrm{C}$ & $5^{\circ} \mathrm{C}$ & $0^{\circ} \mathrm{C}$ & $5^{\circ} \mathrm{C}$ & $0^{\circ} \mathrm{C}$ & $5^{\circ} \mathrm{C}$ \\
\hline \multirow[t]{3}{*}{$\mathrm{I}$} & 0 & 7.73 & 7.73 & 72.1 & 72.1 & 18.65 & 18.65 \\
\hline & 5 & 8.20 & 8.33 & 140.6 & 115.1 & 26.94 & 30.56 \\
\hline & 10 & 8.43 & 8.40 & 152.1 & 161.5 & 26.00 & 34.19 \\
\hline \multirow[t]{3}{*}{ II } & 0 & 7.62 & 7.62 & 104.0 & 104.0 & 23.83 & 23.83 \\
\hline & 5 & 8.18 & 8.27 & 129.2 & 134.2 & 27.45 & 42.99 \\
\hline & 10 & 8.54 & 8.28 & 128.8 & 156.4 & 23.83 & 31.59 \\
\hline \multirow[t]{3}{*}{ III } & 0 & 7.68 & 7.68 & 134.9 & 134.9 & 24.86 & 24.86 \\
\hline & 5 & 8.15 & 8.24 & 139.3 & 158.1 & 28.49 & 25.90 \\
\hline & 10 & 8.50 & 8.60 & 165.5 & 198.5 & 69.41 & 70.45 \\
\hline
\end{tabular}

than in marine species, which indicates that even in adequate production conditions, the final indole levels would be lower in this freshwater species.

Based on chemical and microbiological analysis, it was concluded that freshwater prawns (Macrobrachium rosembergii) have a shelf life around 10 days when stored at $0^{\circ} \mathrm{C}$. The shelf-life is reduced to around 5 days when the storage temperature is increased to $5^{\circ} \mathrm{C}$. The indole production does not appear to be a good indicator of quality and spoilage of the product stored under refrigeration, since it is produced mainly by mesophilic microorganisms in temperatures above $5^{\circ} \mathrm{C}$. Therefore, indole production should not be used alone as an index, but in conjunction with other tests which could indicate improper storage of raw material under inadequate temperature.

\section{RESUMO}

\section{Alterações químicas e microbiológicas do camarão da Malásia (Macrobrachium rosembergii) armazenado sob refrigeração}

Foram estudadas alterações químicas e microbiológicas do camarão da Malásia, armazenado a $0^{\circ} \mathrm{C}$ e $5^{\circ} \mathrm{C}$ durante 10 dias, enfatizando-se a produção de indol como indicador da deterioração. A microbiota psicrotrófila total e indol positiva era predominantemente mesófila, sendo a indol positiva inferior a $10 \%$ da total após 10 dias de armazenamento sob refrigeração, sendo constituida por bactérias das famílias Enterobacteriaceae e Vibrionaceae. O método de Número Mais Provavel-NMP, usando-se o caldo triptona, revelou-se o mais adequado na contagem da microbiota indol positiva. Nas amostras observaram-se o aumento de $\mathrm{pH}$, dos teores de L- triptofano e de bases voláteis totais-BVT, mais evidentes a $5^{\circ} \mathrm{C}$. Nas amostras armazenadas a $0^{\circ} \mathrm{C}$ não foram constatados valores de contagem total de psicrotrófilos e de BVT acima dos limites recomendados $\left(10^{7} \mathrm{CFU} / \mathrm{g}\right.$ e $30 \mathrm{mgN} / 100 \mathrm{~g}$, respectivamente) mesmo após 10 dias de estocagem. No entanto, nas mantidas a $5^{\circ} \mathrm{C}$, estes valores foram detectados após 10 e 5 dias, respectivamente. A presença de indol em níveis acima de $25 \mu \mathrm{g} / 100 \mathrm{~g}$, limite adotado pela FDA/USA, somente foi detectada em uma amostra, sugerindo que esta substância, isoladamente, não seria um bom indicador da qualidade do camarão armazenado sob refrigeração.

Palavras-chave: camarão da Malásia, vida útil, indol

\section{REFERENCES}

1. Association of Official Analytical Chemists-AOAC. Official methods of analysis, AOAC, Washington D.C.,1995,

2. Chang, O.; Cheuk, W.L.; Nickelson, R.; Martin, R.; Finne, G. Indole in shrimp: effect of fresh storage temperature, freezing and boiling. J. Food Sci. 48:813816, 1983.

3. Cheuk, W.L.; Finne, G. Modified colorimetric method for indole in shrimp. J. AOAC 64(4): 783-786,1981.

4. Contreras, E.G.; Guimarães, J.L. Nova reação para determinação de triptofano em alimentos. IV Mostra de Trabalhos Científicos da UNICAMP, Campinas, 1993, v.1, p.239-246.

5. Gram, L. Identification, characterization and inhibition of bacteria isolated from tropical fish. Lingby, 1989, 250p.(Ph.D. thesis, Royal Veterinary and Agricultural University, Lingby,Denmark).

6. Guzman, E.S.C. Métodos químicos para análise de pescado. In: Kai, M.; Ruivo, U.E.(eds) Seminário sobre controle de qualidade na industria de pescado, Leopoldianum Editora, 1989, p.196-209.

7. Holt, J.G.; Krieg, N.R.; Sneath, P.H.A.; Staley, J.T.; Williams, S.T. Bergey's manual of determinative bacteriology. Williams \& Wilkins, Baltimore, 1994, $787 \mathrm{p}$.

8. Howgate, P. Determination of total volatile bases. Torry Research Station, Aberdeen, Scotland, 1976, TD564.

9. Huss, H.H. Assurance of seafood quality FAO-DANIDA, Rome, 1993, 169p

10. Instituto Adolfo Lutz-IAL. Normas analíticas do Instituto Adolfo Lutz, IAL, São Paulo, 1985.

11. International Commission on Microbiological Specifications for FoodsICMSF. Microorganisms in foods. 2-Sampling for microbiological analysis: 
principles and specific applications University of Toronto Press, Toronto, 1986, 293p

12. Jackson, T.C.; Acuff, G.R.; Dickson, J.S. Meat, poultry, and seafood. In: Doyle, M.P.; Beuchat, L.R.; Montville, T.J. (eds) Food microbiologyfundamentals and frontiers, ASM, Washington, 1997, p.83-100.

13. Leitão, M.F.F.; Silveira, N.F.A. Influência da temperatura ambiental na natureza e potencial deteriorador da microbiota bacteriana de peixes em ambientes lacustres tropicais. Colet. ITAL, Campinas, 23 (1):85-97, 1993.

14. Lima dos Santos, C.A. The storage of tropical fish in ice. Trop. Sci. 23:97127,1981

15. Liston, J. Fish and shellfish and their products. In: International Commission on Microbiological Specifications for Foods-ICMSF (eds) Microbial ecology offoods vol.2- Food commodities, Academic Press, New York, 1980, p.567605.

16. Mac Faddin, J.F. Biochemical tests for identification of medical bacteria, The Williams \& Wilkins Co., Baltimore, 1976, 312p.

17. National Research Council. An evaluation of the role of microbiological criteria for foods and food ingredients. National Academy Press, Washington D.C., 1985,436 p.
18. Nip, P.W.; Zeidan, M.K.; Moy, J.H. Aminoacid profile of insoluble collagen isolated from freshwater prawn Macrobrachium rosembergii. J. Food Sci. 46(5):1633-1634,1981.

19. São Paulo (Estado). Código Sanitário: Decreto n 12342, de 27 de setembro de 1978 - Regulamento da Promoção, Preservação e Recuperação da Saúde no Campo de Competência da Secretaria de Estado da Saúde, São Paulo, Imprensa Oficial, 1991, p.167-171.

20. Shamsad, S.I.; Nisa, K.; Riaz, M.; Zuberi, R.; Quadri,R.B. Shelf life of shrimp. (Penaeus merguiensis) stored at different temperatures. J. Food Sci. 55(5):1201-1205,1990.

21. Smith, R.; Nickelson, R.; Martin, R.; Finne, G. Bacteriology of indole production in shrimp homogenates held at different temperatures. J. Food Prot. 47(11): 861-864,1984.

22. Tavares, M.; Aued, S.; Bacetti, L.B.; Zamboni, C.Q. Métodos sensoriais, físicos e químicos para análise de pescado. In: Kai, M.; Ruivo, U.E. (eds), Controle de qualidade de pescado.Leopoldianum Editora, Santos, 1988, p.117-134.

23. Vanderzant, C.; Splittstoesser, D.F. Compendium of methods for the microbiological examination of foods. American Public Health Association, Washington D.C., 1992, 1219 p. 